\title{
Newzealandske gletschere - nogle af Verdens mest klimafølsomme
}

Af Mette Riger-Kusk, ph.d.-studerende, University of Canterbury, New Zealand

Svingninger i udbredelsen af Verdens ismasser er en af de mest pålidelige indikatorer for ændringer i de klimatiske forhold. Men selv i et så begrænset område som New Zealand findes der store regionale forskelle på gletschernes respons på klimaforandringer. Dette ses tydeligt i dag, hvor nogle gletschere oplever en dramatisk tilbagetrækning, alt imens andre vokser.

En gammel Maori-legende fortæller historien om, hvordan en af New Zealands mest imponerende gletschere blev dannet:

Hinehukatere elskede at klatre i bjergene og overtalte sin elskede, Tawe, til at klatre med sig. Tawe faldt tragisk fra bjergtoppen og døde. Hinehukatere blev overvældet af sorg og hendes mange, mange tårer frøs til is og dannede gletscheren Ka Roimata o Hine Hukatere (Lavinepigens tårer).

\section{Tidlige observationer er sjældne}

De fleste mennesker kender Ka Roimata o

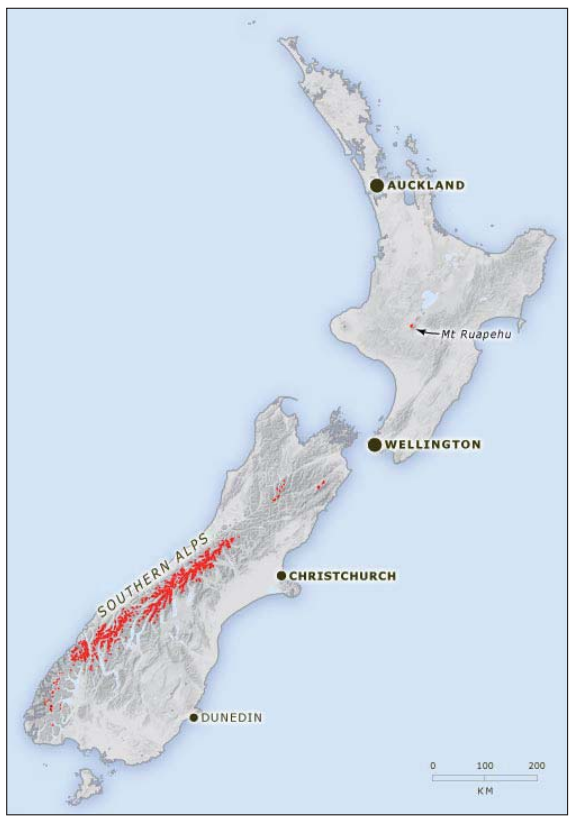

Kort over New Zealand. Med rødt er angivet positionerne for landets gletschere. (Kilde: Trevor Chinn)

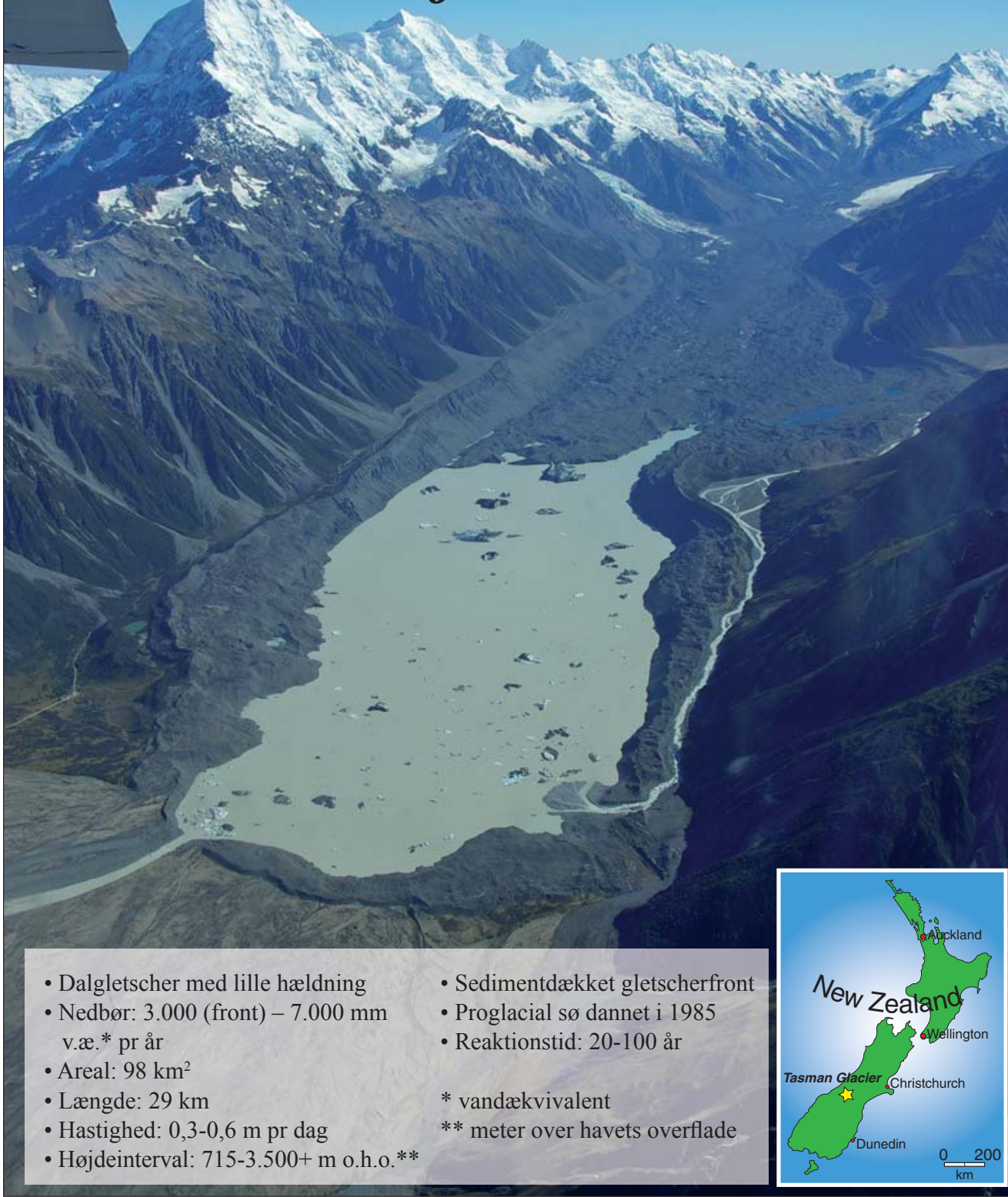

Fotoet viser den nedre del af Tasman Glacier og dens proglaciale sø. Søen er opdcemmet af en morcene aflejret under Den Lille Istid og fyldt med kcelvede isbjerge. (Foto: Mette Riger-Kusk)

Hine Hukatere som Franz Josef Glacier, et navn givet til gletscheren i 1863 af den tyske landinspektør og geolog Julius von Haast, der producerede nogle af de første kort og malerier af newzealandske gletschere.

Tidlige observationer af gletschere er sjældne i New Zealand ikke kun på grund af landets relativt korte videnskabelige historie, men også på grund af den ufremkommelige natur, der kan være noget af en udfordring selv for den ivrige glaciolog. De fleste gletschere ligger højt oppe i bjergene og langt fra beboede områder, hvilket gør langvarige videnskabelige programmer vanskelige. Men er man villig til at acceptere strabadserne, udgør sne- og is-forsk- ninggrupperne i New Zealand et åbent og inspirerende arbejdsmiljø med uendelige forskningsmuligheder og med et godt samarbejde mellem universiteter og andre forskningsinstitutioner.

Disse grupper arbejder i øjeblikket især med, hvordan udbredelsen af newzealandske gletschere har varieret over tid, og hvordan denne viden kan anvendes til at forudsige, hvordan gletscherne vil reagere overfor fremtidige klimaforandringer.

På grund af deres ekstremt store årlige massetilvækst (akkumulation) og -tab (ablation) er gletscherne blandt nogle af Verdens mest klimafølsomme, og de har som følge deraf også oplevet store svingninger i volu- 


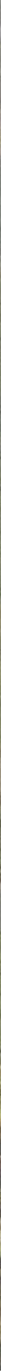

The Franz Josef Glacier/Ka Roimata o Hine Hukatere. Fotografiet viser fronten af gletscheren. (Foto: Trevor Chinn)

men før i tiden. Nye dateringsteknikker så som registrering af koncentrationer af radioaktive isotoper tilført ved kosmisk stråling efter aflejring og eksponering (Surface Exposure Dating, SED) har for nylig med stor succes været anvendt til at aldersbestemme holocæne newzealandske moræneaflejringer. Resultaterne har givet nye fascinerende oplysninger om svingninger i udbredelsen af gletschere på den sydlige halvkugle og vil bidrage til forståelsen af mønstre og timing af klimaændringer mellem den nordlige og sydlige halvkugle.

\section{New Zealands gletschere}

New Zealand ligger mellem $34^{\circ} \mathrm{S}$ og $47^{\circ}$ $\mathrm{S}$ på grænsen mellem subtropiske og subpolare vand- og luftmasser. Ændringer i placeringen af denne grænse sker som følge af ændringer i El Niño Southern Oscillation (ENSO), der kan føre til både årlige og flerårige variationer, hvilket direkte påvirker massebalancen (forholdet mellem akkumulation og ablation) for landets gletschere. El Niño resulterer normalt i lavere luft- og vandtemperaturer og øget nedbør. La Niña derimod bringer højere temperaturer og mindre nedbør og derfor mindre gunstige betingelser for udbredelse af gletschere. Undersøgelser har vist, at variationer i New Zealands gletschere primært er kontrolleret af ændringer i lufttemperaturen og i mindre grad ændringer i nedbørsmængden.

Der findes mere end 3.100 tempererede, maritime gletschere i New Zealand med størrelser over $0,01 \mathrm{~km}^{2}$ (se kort). Samlet udgør de et areal på $1.158 \mathrm{~km}^{2}$ og et volumen på 53 km³ , med Tasman Glacier som den største. Næsten alle New Zealands gletschere findes på Sydøen i bjergkæden kaldet Southern Alps. Med en gennemsnitlig højde på mellem 2.000 og 3.000 meter fungerer bjergene som en $600 \mathrm{~km}$ lang barriere for de vestlige vinde, der dominerer på den sydlige halvkugle. Mount Cook (3.754 m) er det højeste bjerg, og de fleste gletschere ligger i dets nærhed (på 43,5 $5^{\circ} \mathrm{S}$ ). Der findes en kraftig nedbørsgradient på tværs af bjergene med nedbørsmængder på op til $12.000 \mathrm{~mm}$ vandækvivalent (v.æ.) per år på vestsiden og mindre end $1.000 \mathrm{~mm}$ per år på østsiden. På Nordøen findes der alene gletschere på Mount Ruapehu-vulkanen.

\section{Bjerg- og dalgletschere}

New Zealands gletschere kan groft inddeles $\mathrm{i}$ to hovedkategorier: stejle bjerggletschere, der bevæger sig med høj hastighed og dalgletschere, der er mindre stejle og flyder med en lavere hastighed. Fronten af dalgletschere er typisk dækket af et isolerende sedimentdække, og flere har for nylig udviklet hastigt ekspanderende søer foran gletscherfronten, de såkaldte proglaciale søer.

Den tid, det tager for en gletscher at tilpasse sig til en ændring i klimaet, afhænger af dens størrelse, form og hældning. De stejle bjerggletschere har en usædvanligt stor akkumulation og ablation og intet isolerende sedimentdække. Derfor tilpasser de sig hurtigt til forandringer i klimaet, hvilket kan observeres som en tilbagetrækning eller fremrykning af gletscherfronten inden for 
en periode på 5 til 20 år. I modsætning hertil findes de mindre stejle sedimentdækkede dalgletschere, der kan have en reaktionstid på op til et hundrede år. Selv om afstanden mellem dem er mindre end $5 \mathrm{~km}$, er Franz Josef Glacier, der ligger på Sydøens vestkyst, et typisk eksempel på den første kategori, mens Tasman Glacier længere mod øst tilhører den anden kategori.

At beskrive alle New Zealands gletschere ved de to typer nævnt ovenfor er selvfølgelig en grov forenkling. De to eksempler illustrerer dog de store dynamiske forskelle, der eksisterer mellem gletschere og det endda inden for et meget lille geografisk område. Det er derfor ikke så enkelt at finde en god måde at overvåge de mange meget forskellige gletschere, især når de traditionelle metoder såsom detaljerede massebalance-undersøgelser er arbejdskraftintensive og dyre at vedligeholde.

\section{Overvågning af gletschere}

Registrering af ændringer i gletschernes længder er den enkleste metode til at overvåge gletschere. De observerede svingninger afhænger imidlertid af reaktionstiden for hver enkelt gletscher, og som ovenstående eksempler dokumenterer, kan denne variere betydeligt fra gletscher til gletscher. En alternativ og relativt simpel og hurtig metode at kortlægge massebalancen for en gletscher er ved at registrere placeringen af snegrænsen $i$ slutningen af sommeren. Denne linie repræsenterer grænsen mellem akkumulations- og ablationsområdet på en gletscher (også kaldet ligevægtslinien), og årlige udsving af denne linie kan anvendes som et billede på ændringer i massebalancen (se billede).

I New Zealand er fotografier af snegrænsen i slutningen af sommeren blevet indsamlet fra et lille fly siden 1977. Disse undersøgelser har bidraget med detaljeret viden om newzealandske gletscheres specifikke følsomhed og dynamik og har tydeliggjort forskellene mellem de forskellige gletschere. Andre projekter har foretaget detaljerede undersøgelser af massebalancen for enkelte gletschere, og modelleringsstudier har fremmet forståelsen af gletschernes respons til klimaforandringer. For nyligt er gamle moræneaflejringer i Mount Cook-området blevet præcist dateret ved hjælp af af SED, der er en relativt ny dateringsteknik. Resultatet er en yderst detaljeret kronologi for holocæne svingninger i udbredelsen af gletschere i New Zealand.

Flere forskningsprojekter har vist, at de New Zealandske gletschere på tidspunkter i historien har opført sig markant anderledes end ismasserne på den nordlige halvkugle. Selvom en betydelig fremrykning af gletscherne fandt sted i New Zealand under Den Lille Istid, så genvandt de newzealandske gletschere ikke samme størrelse, som de havde for 6.500 år siden. Det står i stærk kontrast til de fleste gletschere på den nordlige halvkugle, hvor det maksimale holo-

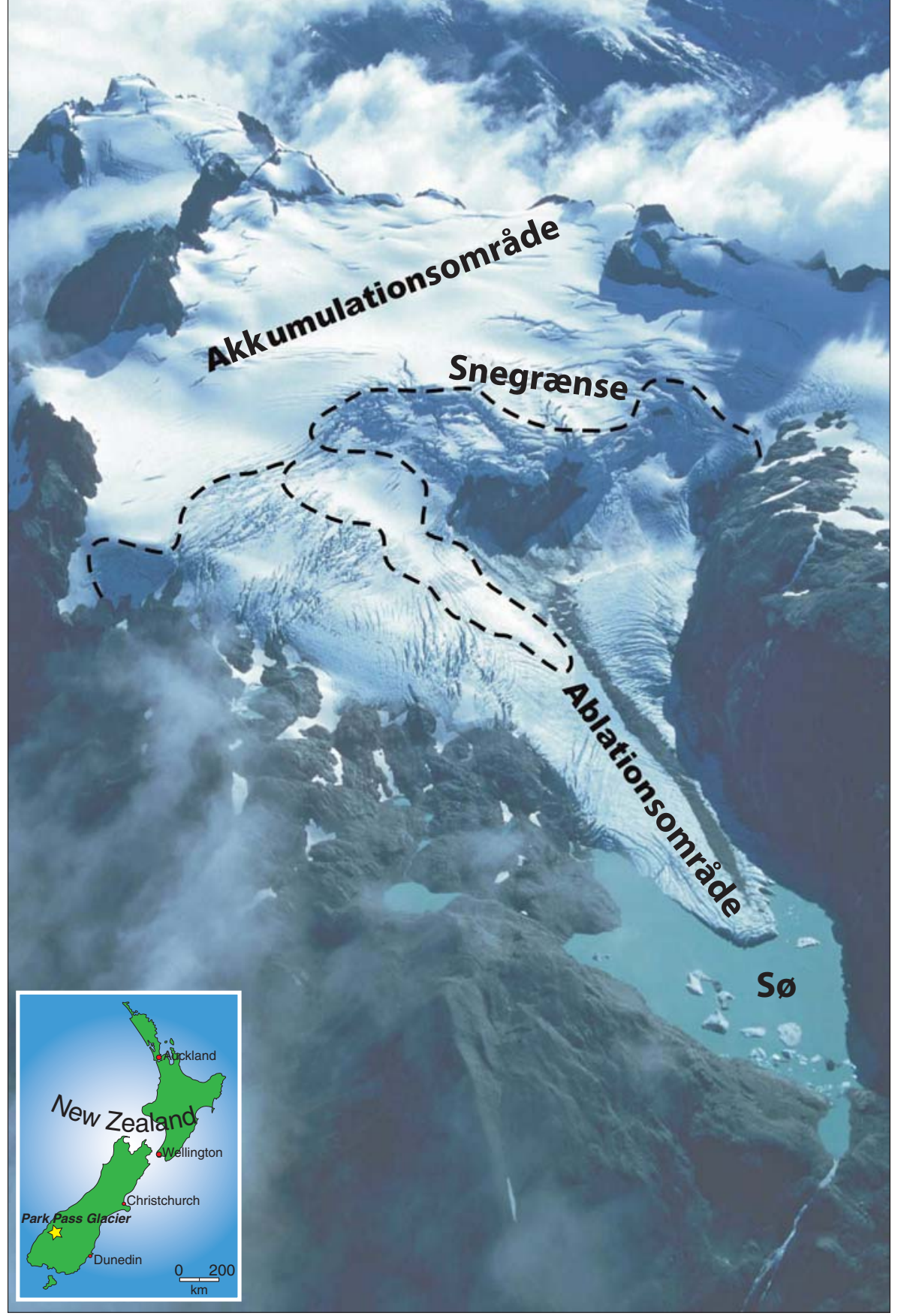

Park Pass Glacier i slutningen af sommeren 2007. Med stiplet er angivet snegrcensen, der deler gletscherens akkumulationsområde fra ablationsområdet. Endringer fra år til år $i$ placeringen af denne linie kan bruges som et billede på cendringer i massebalancen. (Foto: Trevor Chinn)

Grafen viser placeringen af fronten af Franz Josef Glacier siden slutningen af Den Lille Istid. (Kilde: UVH modificeret efter Brian Anderson, Victoria University, New Zealand)

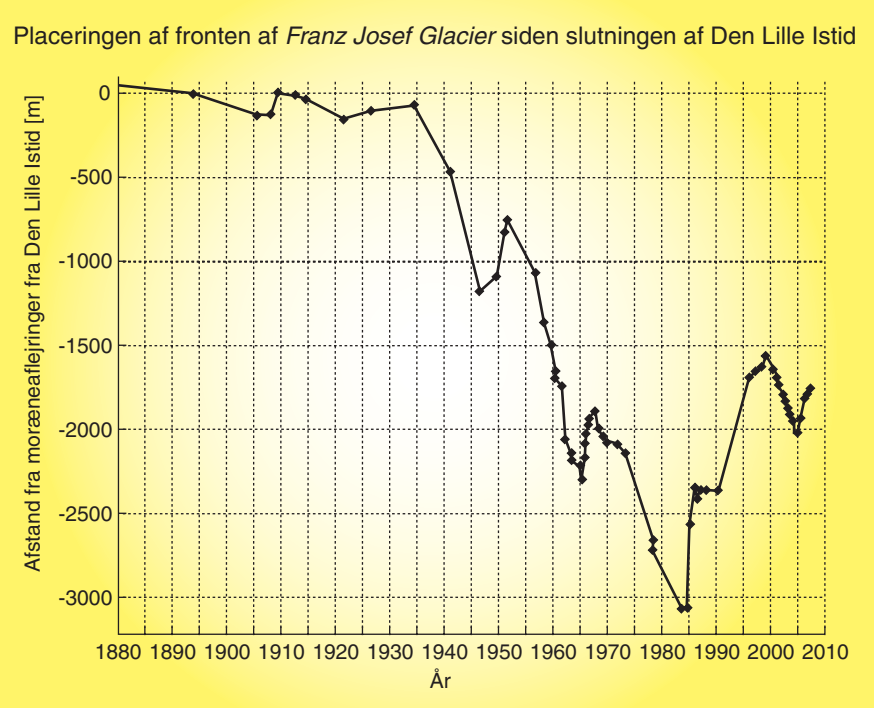


cæne isudbredelse netop forekom under Den Lille Istid (1300-1860 f.Kr.).

De nye dateringer viser, at gletscherne i Mount Cook-området adskillige gange gennem Holocen har oplevet vækst under relativt varme perioder på den nordlige halvkugle. Desuden ser det ud som om, at timingen for den maksimale isudbredelse i New Zealand under Den Lille Istid fandt sted lidt tidligere end på den nordlige halvkugle. Disse forskelle giver evidens om betydningen af regionale klimatiske faktorer, når man diskuterer mekanismerne $\mathrm{i}$ forbindelse med globale klimaforandringer.

Mellem 1750 og 1890 e.Kr., som markerede afslutningen af Den Lille Istid i New Zealand, begyndte en udbredt tilbagetrækning og udtynding af landets gletschere. Dette skete som et resultat af en temperaturstigning på omkring $1{ }^{\circ} \mathrm{C}$. Fx trak Franz Josef Glacier sig cirka $3 \mathrm{~km}$ tilbage i perioden mellem den første undersøgelse af gletscheren i 1894 og dens korteste udstrækning målt i 1984 (se graf på forrige side).

I modsætning hertil har gletschere med længere reaktionstider undergået mindre ændringer. Tasman Glacier havde fx den samme længde fra Den Lille Istid og indtil 1985 på trods af en 160 m sænkning af gletscheroverfladen i den nederste del. Fotografierne nedenfor illustrerer de store ændringer, der er sket for Stocking, Hooker og Mueller Glacier siden begyndelsen af 1900-tallet. Alle tre gletschere har trukket sig betydeligt tilbage, men for Hooker og Mueller Glacier har tilbagetrækningen været specielt dramatisk på grund af dannelsen af proglaciale søer.

Da indsamlingen af billeder af snegrænsen på gletscherne startede i slutningen af sommeren i 1977 faldt det tilfældigvis sammen med en større ændring i den atmosfæriske cirkulation. La Niña havde været udbredt siden 1940'erne, men med en ændring til El Niño i slutningen af 1970erne resulterede det i mere gunstige betingelser for gletscheren. De højdynamiske gletschere reagerede hurtigt, og Franz Josef Glacier er for eksempel rykket over $1.000 \mathrm{~m}$ frem siden den mindste målte udstrækning i 1984 (se grafen på forrige side).

I den samme periode har dalgletschere generelt stoppet deres tilbagetrækning og fremrykninger forekommer nogle steder. Men for nogle gletschere, såsom Tasman Glacier, har dannelsen af proglaciale søer mellem gletscherfronten og den opdæmmende moræne fra Den Lille Istid resulteret $i$ en dramatisk tilbagetrækning af gletscheren på grund af kælvning og øget ishastighed. I 2008 var søen foran Tasman Glacier $7 \mathrm{~km}$ lang, $2 \mathrm{~km}$ bred og havde en maksimal dybde på $245 \mathrm{~m}$ og til i dag, fortsætter søen med at reducere størrelsen af gletscheren.

\section{Fremtidigt perspektiv}

Selv om New Zealands gletschere i øjeblikket generelt oplever gunstige forhold, forudser The Intergovernmental Panel on

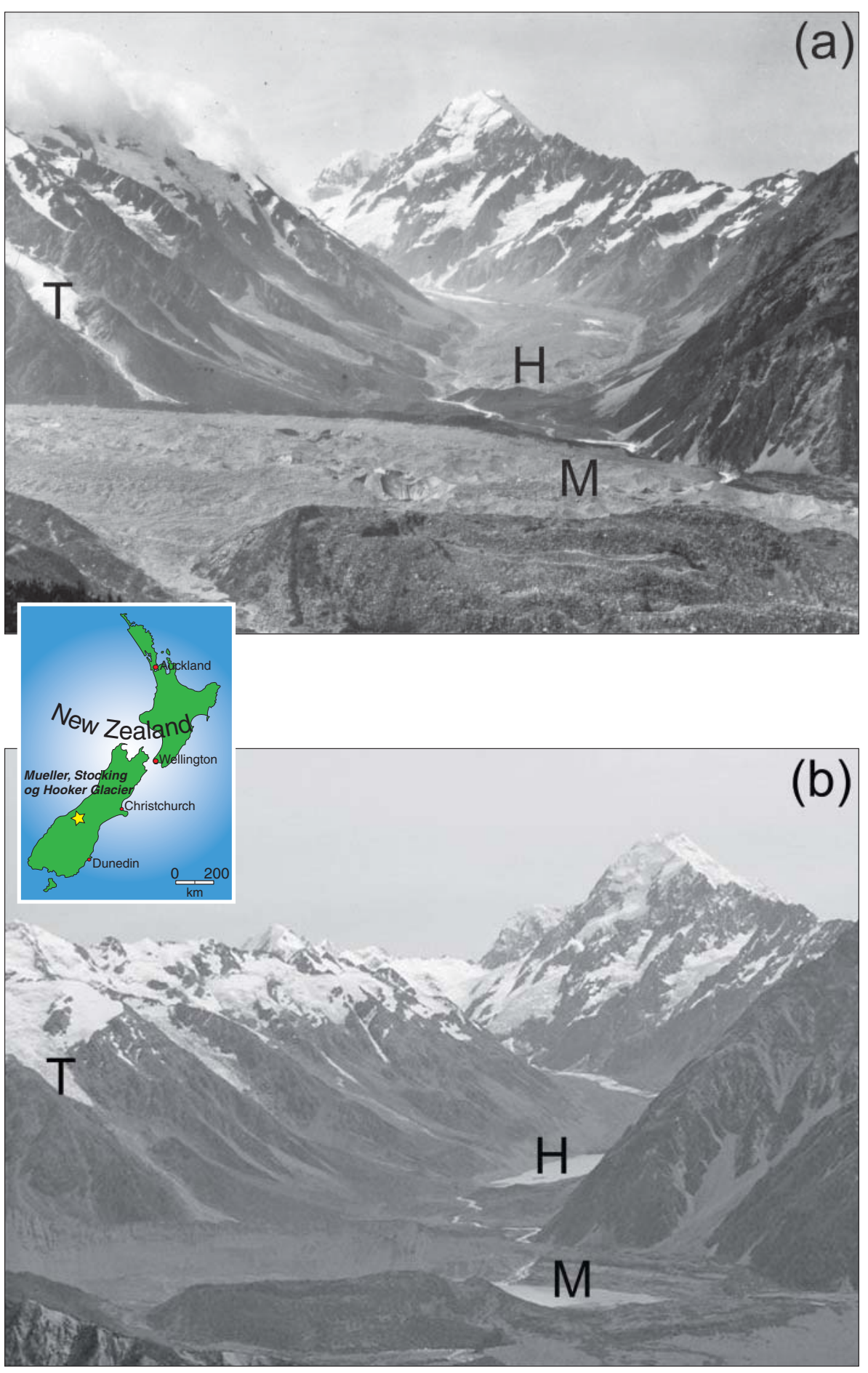

Mount Cook i baggrunden med Stocking (Tawaewae) Glacier (T), Hooker Glacier $(H)$ og Mueller Glacier (M). ((a) Billedet er taget af Ebenezer Teichelmann mellem 1901 og 1910 og stammer fra Kennedy Indsamlingen i Canterbury Museum. (b) Nyligt fotografi taget af Heather Purdie. Kilde: Tim Kerr og Ian Owens, University of Canterbury, New Zealand)

Climate Change (IPCC), at den afsmeltning og tilbagetrækning af ismasser, der har fundet sted over hele kloden siden Den Lille Istid, højst sandsynligt kommer til at fortsætte. Som tidligere nævnt er newzealandske gletschere særligt følsomme over for disse ændringer på grund af det maritime klima og den tilhørende store ablation og akkumulation.

Resultater fra projekter, der har til formål at modellere udbredelsen af gletschere, viser, at Franz Josef Glacier står til at miste omkring $38 \%$ af dens nuværende volumen og vil trække sig yderligere $5 \mathrm{~km}$ tilbage i løbet af de næste 100 år forudsat et middel globalt opvarmnings-scenarium (for sydvest New Zealand: $+1,4{ }^{\circ} \mathrm{C}$ og $+8,0 \%$ nedbør i 2100). På grund af den store højde, som den øvre del af gletscheren ligger i, er den dog betydelig mere modstandsdygtig over for en fremtidig temperaturstigning end hovedparten af New Zealands gletschere.

Under det samme klimatiske scenarium forventes $49 \%$ af landets gletschere at ligge 
inden for zoner med negativ årlig massebalance. Dette vil føre til fuldstændig smeltning af mange af gletscherne og dermed bidrage til en stigning i det globale havniveau. Mere lokalt forventes mindskelsen af gletscherne at få en negativ effekt på blandt andet New Zealands turisme og den hydroelektriske energiproduktion.

Forskningsprojekter i New Zealand har i de seneste år bidraget betydeligt til diskussionen om drivmekanismerne for globale klimaforandringer. Resultater af disse undersøgelser viser forskelle i respons og timing af gletscherne i New Zealand i forhold til ismasser på den nordlige halvkugle. Dette påviser betydningen af regionale klimatiske variationer, såsom El Niño og La Niña, i forståelsen af globale klimaforandringer.

Forhåbentlig vil nogle af de mange nye og spændende newzealandske forskningsprojekter resultere $\mathrm{i}$ en forbedret generel forståelse af gletschers dynamik og som konsekvens deraf gøre det muligt at opstille sceanarier for deres respons på den forventede globale opvarmning.

For yderligere information anbefales artikler publiceret af følgende forskere:

Trevor Chinn, Brian Anderson og Joerg M. Schaefer.

Satellitbillede af et skyfrit New Zealand midt på sommeren, hvor områder med is ses tydeligt. (Copyright: Jacques Descloitres, MODIS Rapid Response Team, NASA/GSFC)

\section{Kort nyt}

\section{Mammutfund på Falster}

Den 20. april fandt en inkarneret fossilsamler en stødtand fra en mammut i Nørre Tåstrup Grusgrav på Falster. Fossilsamleren, Peter Bennicke, fik egentlig stødtanden foræret i grusgraven, idet han kom i snak med en ny medarbejder i den grusgrav, hvor han var kommet for at hente byggematerialer.

Da Peter Bennicke fortalte ham om sin passion for fossiler, viste medarbejderen $\mathrm{i}$ grusgraven ham noget, som han syntes så underligt ud på et brønddæksel ved en stak træpaller. Peter Bennicke vidste straks, at der var tale om en mammut-stødtand og fik hurtigt kontaktet Zoologisk Museum på Falster, der registrerede og bekræftede fundet. Mammutten har ikke levet på dansk jord, eftersom den vandrede rundt på de store sletter for mellem 14.000 og 40.000 år siden. Istidens ismasser hat transporteret tanden, som i flere tusinde år har ligget på bunden af Grønsund. Her blev den så sidste år gravet frem af en stenfiskerbåd og læsset af i Nørre

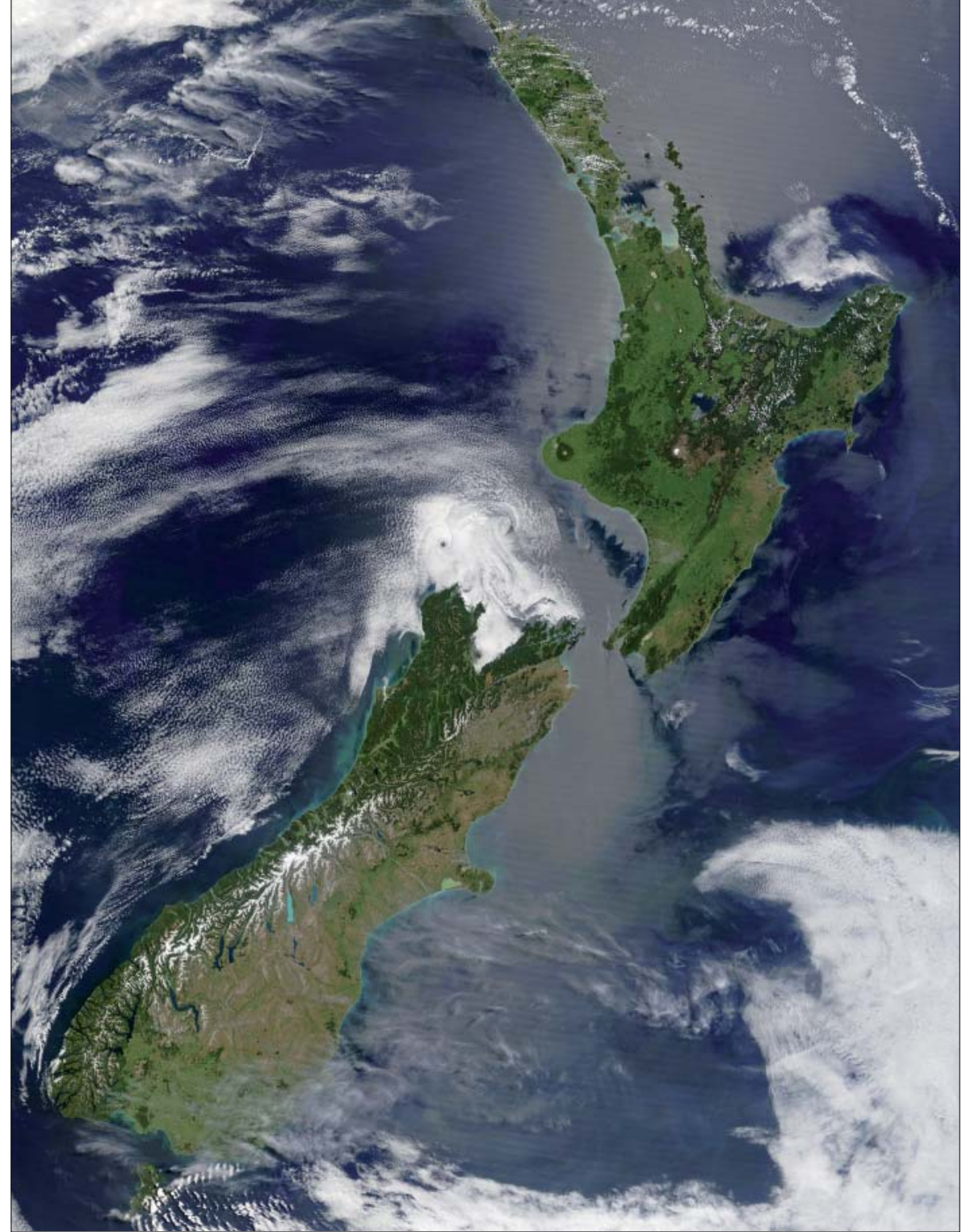

Tåstrup Grusgrav. En medarbejder i grusgraven troede, at det var en gren og lagde mammuttanden på brønddækslet, inden den skulle ind i grusgravens sorteringsmaskine.

Peter Bennicke har fået lov til at beholde den 4,2 kg tunge og knap $50 \mathrm{~cm}$ lange tand, som han nu udstiller på sit private sten- og fossilmuseum på Falster.

$J P / S L J$

\section{Afghansk jordskælv}

To jordskælv rystede $d$. 17 . april med to timers mellemrum den østlige del af Afghanistan i et afsidesliggende område i provinsen Nangarhar ved grænsen til Pakistan. Jordskælvene, der blev målt til hhv. 5,5 og 5,1 på Richterskalaen, og som havde deres epicentre i hhv. tre og otte kilometers dybde, ramte flere landsbyer og lagde snesevis af boliger i ruiner. 22 mennesker blev meldt omkomne efter de første meldinger fra det afghanske politi.

AFP/SLJ 